\title{
Developing Cultural Tourism Strategies in Lithuania
}

\author{
Malvina Arimavičiūtė \\ Mykolas Romeris University \\ Valakupiu str. 5, LT-10101 Vilnius, Lithuania \\ DOI:10.13165/VPA-15-14-2-12
}

\begin{abstract}
This paper determines that cultural tourism in Lithuania is significantly influenced by various different agencies which activities are not sufficiently integrated. The paper also analyses the theoretical models for strategic decision-making and possibilities of alternative strategic decisions in the area of tourism. A classification of strategic plans based on the current Lithuanian strategic planning system and the integration of the activities of separate agencies in the area of tourism is proposed. A new model for strategic decision-making based on the classical definition of strategic hierarchies and the specificities of cultural tourism as a business is then proposed.
\end{abstract}

Keywords: cultural tourism, marketing strategy, corporate strategy, strategy of business units, functional strategies, regional level strategies, specialized tourism strategies.

Raktažodžiai: kultūrinis turizmas, rinkodaros strategija, korporatyvine strategi$j a$, verslo vienetu strategija, funkcinès strategijos, regioninio lygmens strategijos, specializuotos turizmo strategijos.

\section{Introduction}

Tourism plays a very important role not only in the contemporary economy of Europe, but also in Lithuania. In the EU travel, tourism and related sectors make up around $10 \%$ of the EU's GDP [12], while according to preliminary calculations, it is estimated to be at around 4\% [16]. Tourism related resources are one of the most important competitive advantages when seeking to attract tourists and enhance the economic benefits of tourism. The resources of Lithuanian tourism, their structure of attractiveness are completely in tune to the market of Northern and Central 
European tourism resources. The variety and abundance of tourism related resources in Lithuania allows creating and developing cultural and explorative tourism and orienting them towards the relevant segments of the market.

The importance of cultural tourism in Lithuania can be studied from the perspectives of financial, knowledge and social capital accumulation. The most important concern of the state when developing cultural tourism is to increase its budget and also to provide opportunities for international integration. The needs of consumers are connected to the educational activities, encouraging discovering the cultural infrastructure and the unique nature of specific locations. Cultural tourism is greatly influenced by the current global tendencies of changing family roles, the diminishing of religious practice, increasing consumerism and other changes in the social needs of consumers. Other sectors of the Lithuanian economy, such as environmental protection, agriculture, transportation, culture, are affected both positively and negatively by the development of cultural tourism. It is imperative to balance the activities of cultural tourism in the state, regional and institutional levels and create a rational system of management, based on the principles of balanced development to minimize the possible negative effects.

The definition of cultural tourism was analysed by Richards [22], Silberberg [25], Tighe [28], Hall and Zeppel [6], McKercher and Du Cros [17]. The trends of cultural tourism development were studied by Akama and Sterry [1], McKercher and Du Cros [17], Cabrini [3]. The characteristics of Lithuanian cultural tourism, its pros and cons were analysed by Užpelkis [29], Indriūnas [8]. The problems of strategic management of tourism were studied by Evans [4], Poon [18], Žilinskas and Petravičiené [31]. Despite the abundance of academic literature, the specific of Lithuanian cultural tourism from the perspective of strategic management has not been analysed before.

Several problems for the study can be distinguished:

1. The insufficiently integrated activities between the protection of cultural heritage and the development of cultural tourism.

2. In the area of cultural tourism on both levels, the state and regional levels programme management is used. Strategic decisions in the area of cultural tourism do not take into account the separate levels of strategic hierarchy and separate functional activities.

3. There is no model of cultural tourism strategic management created in Lithuania that would emphasise strategic hierarchy and features of activities of tourism focused businesses.

The development of a cultural tourism strategy according to the separate levels of hierarchy and functions, as well as emphasising the function of marketing at the highest levels, would help to better exploit the possibilities of cultural tourism and internal resources, increase the competitiveness of activities and coordinate separate cultural tourism activities. 
The goal of this paper is to analyse the current system of Lithuanian cultural tourism strategic planning and provide a model for developing strategies, based on the levels of strategic hierarchy and functional activities.

\section{The problem of cultural heritage protection and tourism integration}

From the management perspective, cultural tourism in Lithuania has certain distinguishing features. The goals of tourism development in the general structure of Lithuania's economy are influenced and closely connected with the strategies of other sectors of the economy and their measures and objectives. Effective development of tourism is possible only if there exists a balanced organizational structure of all levels and there are strong ties of communication within them [31]. It is strategic planning that helps create a rational structure of balanced development based management. There are no special strategies or programmes developed for cultural tourism in Lithuania. The long-term perspectives of these activities are covered by the common national and regional tourism development documents. The function of managing the Lithuanian tourism sector belongs to the Government, Ministry of Economy, the State Tourism Department and municipalities. The main mid-term strategic document regulating the tourism sector is the National Tourism Development Programme [15]. After the abolishment of county chief administrations in 2010, there were no more administrative departments for culture in counties. Thus, there was a need to clarify the goals of regional culture development by emphasising culture as a very important factor for social and economic development. To achieve this, the Regional Cultural Development Programme for 2011-2020 was drafted. The implementation of this programme is coordinated by the Ministry of Culture. In general, we can say that the responsibility of protecting cultural heritage lies with the Ministry of Culture, while the function of managing cultural tourism belongs to the Ministry of Economy. The activities of these agencies are not integrated enough and this causes not an insignificant amount of problems. The biggest potential for recreation within Lithuania is in its protected territories, however, they are currently not utilized enough, because priority is given for protection and regulated visits and not for the recreational benefits of nature, that is, the zones for recreational activities are minimal, while in zones available for economic activities there are no priorities for recreation. Thus, the needs of all the different tourism infrastructure development are not considered and the lack of infrastructure limits the activities of tourism, creates a barrier to using the existing recreational potential more widely. Because of the complex regulations of registering cultural assets, there being no precise regulations for registering and maintaining cultural assets, it is quite difficult to use these cultural assets for the benefit of tourism. The adaptation of cultural heritage objects for tourism and for the needs of the public would ensure the protection of these objects and would create the conditions to organize cultural, business tourism and recreational activities. It would also increase regional development. 
In the opinion of the National Audit Office of Lithuania, there are essentially no positive changes in the protection of immovable cultural heritage of national significance. The Ministry of Culture has not yet prepared a strategy for saving the immovable cultural heritage that would define such objects, why and how should the state protect them, upon what criteria (priorities) should objects be considered as being worthy of state protection [13].

The National Audit Office in its audit and analysis of the Museum Modernization Programme determined that the programme itself was drafted without having a strategy for museum development, its goals were not oriented to any particular results, the evaluation criteria did not allow to evaluate to what precise level were the objectives achieved and the need for funding was not detailed for all of the measures, in essence not setting the ground for a successful renewal of the programme. The renewal of the material base of museums is not always carried out according to the funding priorities, the assets (exhibits) are obtained, stored, restored and conserved without having any specific priorities, so the conditions for museums to effectively collect, store, restore, display and protect the cultural assets, in turn, a threat rises to the protection of these assets [13].

The Ministry of Culture has not sufficiently taken into account the recommendations of the state audit carried out by the State Control and has not initiated any strategies of national heritage protection or museum development, using only recommendations for specific areas of activities. In Lithuania, there still exists the problem of cultural heritage protection and the integration of culture, infrastructure modernization and cultural tourism development. Although during the 2004-2006 and 2007-2013 EU structural fund programming periods there were funds for adapting cultural heritage objects for tourism, there still exist a need for the 2014-2020 programming period to create conditions to provide funding for the conservation of cultural heritage and not only adapting it for tourism. This would encourage a wider perspective towards the importance of cultural heritage in regional exclusivity and attractiveness in using the opportunities provided by cultural tourism [21]. At the highest level of the Government, there is still a lack of strategic decisions on cultural heritage protection and the development of culture infrastructure in order to encourage cultural tourism. To address this problem, it is imperative to create a Cultural Tourism Development Programme which should be initiated by the Ministry of Economy or Culture. This programme should be implemented through strategic plans of activities. Because the goals and objectives of the programme will be implemented by several assignation holders, they themselves would have to decide on the ways to coordinate this programme. The proposed scheme of documents integrating the Cultural Tourism Development Programme in the system of Lithuanian strategic planning is provided in Figure 1. 


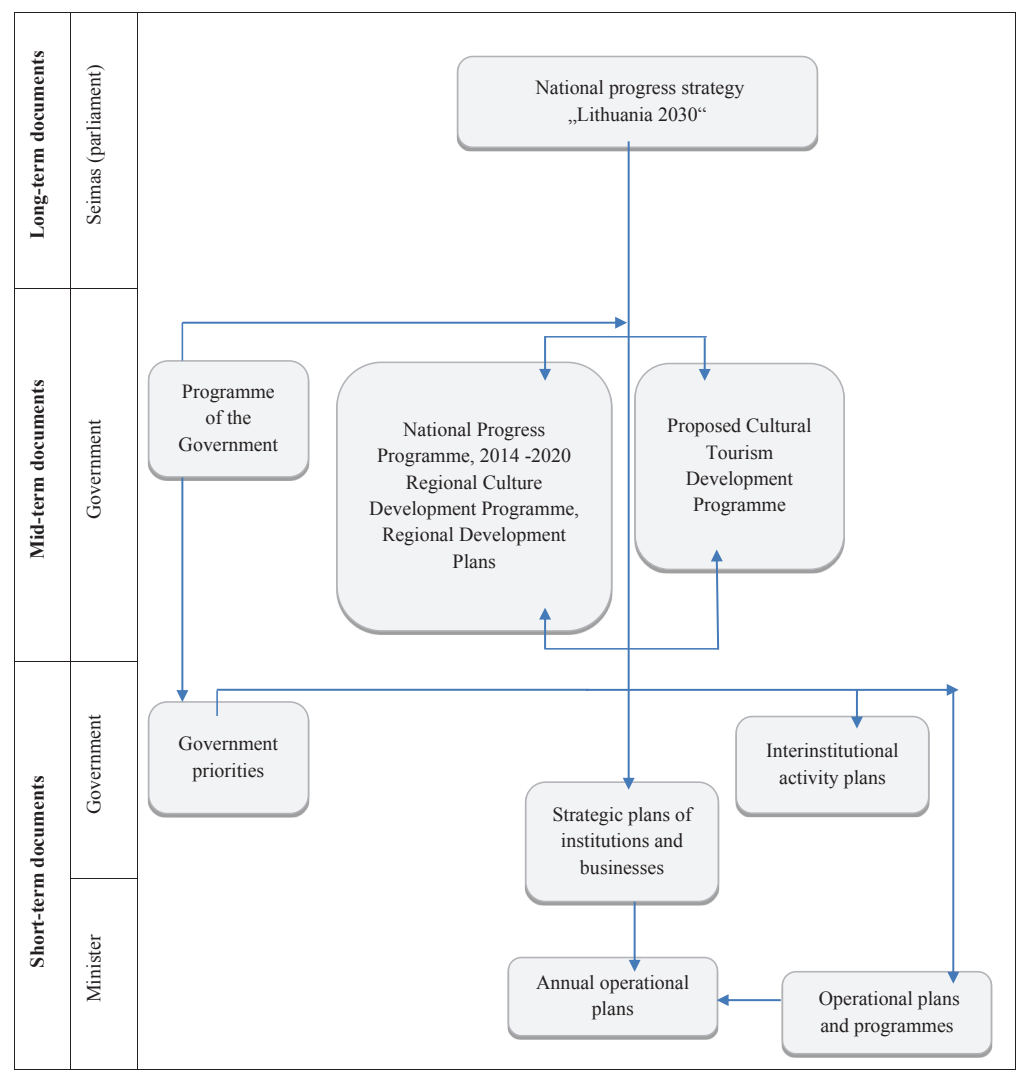

Figure 1. The proposed scheme of documents integrating the Cultural Tourism Development Programme in the system of Lithuanian strategic planning

\section{Hierarchy of cultural tourism strategies}

The main idea behind the strategic planning of cultural tourism in Lithuania is to find the most acceptable way to help cultural tourism achieve the best results in increasing its value in not only the economic aspect. Cultural tourism, as an area of activities, has many goals and is influenced by many interest groups with different and sometimes contrary interests. To ensure that the strategy would better evaluate these interests, it can be drafted at several levels. Delving deeper into the essence of a modern organization as well as the dominating trends, we can agree that such a differentiation of strategies according to hierarchical levels is not without merit $[10, p$. 240]. In the business of cultural tourism, there usually is only one strategy used, which 
is the common strategy. The decision to create strategies for several hierarchical levels is determined by the specific organizations type [10, p. 240]. The highest hierarchical level of strategy is considered to be the integration strategy. It contains all long and middle term state level and specialised tourism strategies and programmes. Its goal is to integrate the area of activity into society in such a way that it would take into account not only the interests of direct interest groups, but also the interests of wider society and other areas of activities. So, the cultural tourism integration strategy is defined by the National Progress Strategy, the Government Programme, National Progress Programme, Regional Cultural Development Programme for 2014-2020 and the proposed cultural tourism development programme.

The second level strategy in the area of tourism would have to be corporate. The strategy of this hierarchical level corresponds to the regional level strategic planning, where the main role belongs to the municipalities and other government structures [30]. The main goal of the corporation strategy is to select and manage a portfolio of tourism services, combine and coordinate the independent and connected business unit strategies, especially in developing tourism routes, as well as determining the financial resources and their allocation priorities. The cultural tourism corporate strategy should address questions related to the provision of new services, better management of the service portfolio. The requirements set forth to this strategy are reflected in the Lithuanian Regional Development plans, which are drafted according to a special development plan methodology [20]. Cultural tourism in these plans is presented as part of the regional economic development priorities, determining appropriate goals and objectives. In more detail, this strategy is reflected in the activity strategic plans of municipalities, which are prepared according to the Government approved strategic planning methodology [14] or the recommendations provided in the Strategic Planning System Improvement in Municipalities Guidelines [26]. It is common that municipalities draft a separate programme for tourism development and a separate programme is created for cultural heritage protection, the interactions of the activities between these programmes is scarcely touched upon.

The third level of strategy is the business unit strategies. Bourgeois describes this strategy as manoeuvring [2]. This strategy is focused on managing separate activities providing tourism services. The strategies of this hierarchical level have to help answer questions, such as how to compete successfully, what competitive advantages should we seek for, what main goals and objectives for the departments of service/ product development, marketing, finance, innovation and human resources are [10]. Porter combines the principal ways of obtaining competitive advantages with the quantitative expressions of the activities and formulates three main strategies: lower prices (cost leadership), differentiation and concentration (niche) [19]. According to this author, there are certain dangers when a firm aims to implement not one but two or three of these strategies at the same time.

When developing cultural tourism in Lithuania, all three competition strategies are acceptable and practically applicable. Also, in some cases (e.g., a private museum 
in Raseiniai), the niche and cost leadership strategies are utilized perfectly. Some authors are still critical of the application of Porter's strategies. Janulienė, Žalienè and Žylys [9, p.89] maintain that Porter's strategies can be used in the sphere of services but are not suitable for the tourism business. Evans [4] also emphasises the problems of applying Porter's general strategies in the business of tourism. Rugman and Verbeke [24] argue that Porter's model does not evaluate such criteria as technology, costs of activities, international competition. The type of competition in cultural tourism is different. If it is normal that in a business the competition happens between business units, in cultural tourism the competition happens in the state, regional and institutional levels. Cultural tourism is closely related to the development of the country and the region's image. Also, the regions compete amongst themselves for state grants, compete between themselves and separate enterprises providing tourism services. Marketing is developed alongside competitiveness.

Fourth level strategies are functional strategies. The main functional strategies are production (or another main activity of transforming resources into products/ services), marketing, finance, innovation and human resource development $[10, p$. 245]. Strategies of this type are usually not created at tourism related enterprises, because their creation would require the managers of these businesses to concern themselves with not only the effectiveness of each functional activity, but also with their coordination. Understandably, these strategies cannot have their own individual goals. They serve to achieve the goals of higher level strategies.

The fifth level strategies are called operational. These are structural department strategies, in municipalities - eldership strategies. Many elderships in Lithuania prepare their annual operational plans. These are documents detailing the implementation of municipality council approved municipality strategic plans programmes (or parts of them - goals, objectives, separate measures, including those related to cultural tourism) in the territory under the administration of the eldership. This plan sets forth specific activities for the eldership, activities that are planned to take place, including those related to cultural tourism. It also determines the appropriate evaluation criteria for the eldership to follow when implementing the measures of the municipality strategic plan's programmes that the eldership is responsible for. The local community is included in the processes of preparation, consideration and evaluation of the results of the annual operational plan.

\section{The cultural tourism strategy development model}

Taking into account the limits of Porter's model for tourism, Poon [18] proposed a model of strategy tailored for the sphere of tourism (including cultural tourism). The characteristics of Poon's model of competitiveness strategy are provided in Figure 2. 


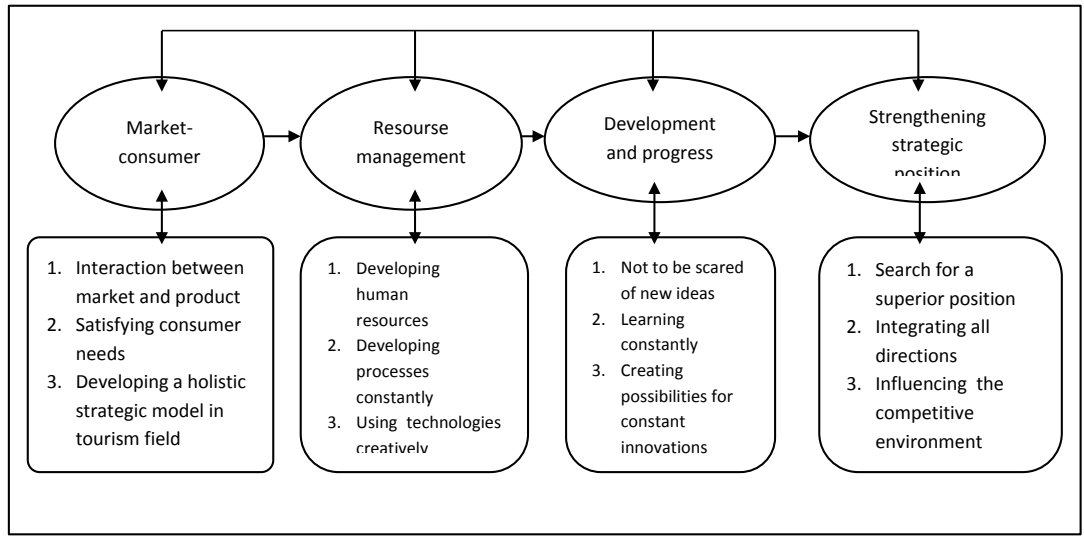

Figure 2. Characteristics of A. Poon's strategy model cycle [18]

In Poon's opinion, to successfully utilize a strategy, there exists a need for travel and tourism businesses to prioritize their customers, take the leadership position in the area of quality, develop the radical use of innovations and strengthen the company's position in the business value chain [18]. Similar strategic characteristics are listed by Franko and Star. According to them, companies wishing to achieve competitive advantages have to realise the main accents, which are quality, innovation, human resource management and flexibility [5], [27]. Quality is an important factor when seeking a competitive advantage, but it is not enough. A customer wants a combination of quality and low cost, while individually quality is considered as something that goes without saying [11]. The first three characteristics of Poon's model (market-customer, resource management and expansion and technology) are closely connected to the functional strategies of marketing, human resources and innovation. Strengthening the strategic position is important in order to increase the competitive advantages of companies, however, it is very universalistic according to the provided ways of strengthening the strategic position. The latter characteristic of the competitive strategy model cycle is worthy of separate analysis. The first factor of strengthening the strategic position is to seek a more advantageous position. However, the position of the company comes about because of many reasons: the experience of the staff, their communication with clients, the result of marketing, etc. It is exactly because of the efforts of marketing that companies can incrementally strengthen or change the positions of its services. Positioning in a tourism company is the creation of an image of the service (or company) in the mind of the consumer, with the goal to exclude the company from its competitors. Position can be carried out using all of the marketing tools, but advertisements work the best. So, positioning, according to certain goals in the company, can be considered to be part of the functional strategy of marketing. Another important factor in strengthening 
the strategic position in the above pictured scheme is the integration in all directions. The main goal of the integration strategy is to achieve synergy by saving exchange costs, better utilizing resources and abilities, developing the assortment of services. It also provides an opportunity to control the quality in several parts of the valuecost chain, differentiate services, lower the general risk of activities by diffusing it in separate units of activities of the value-cost chain, etc. However, strategies of integration in all directions are corporate in nature and they should not be listed as part of functional strategies. The third factor in strengthening the strategic position is influencing the competitive environment. Aggressive strategies can be applied at this point. In general, aggressive strategies can be considered as part of business unit strategies. Januliené, Žalienè and Žalys [9], using Poon's strategy development model, proposed their own model for Lithuanian tourism (including cultural tourism) companies. These authors saw a feedback connection between the strengthening of the strategic position and the market-consumer relation, as well as clearly providing the quality wheel of the tourism company, and so emphasising the importance of quality in the tourism business (Figure 3).

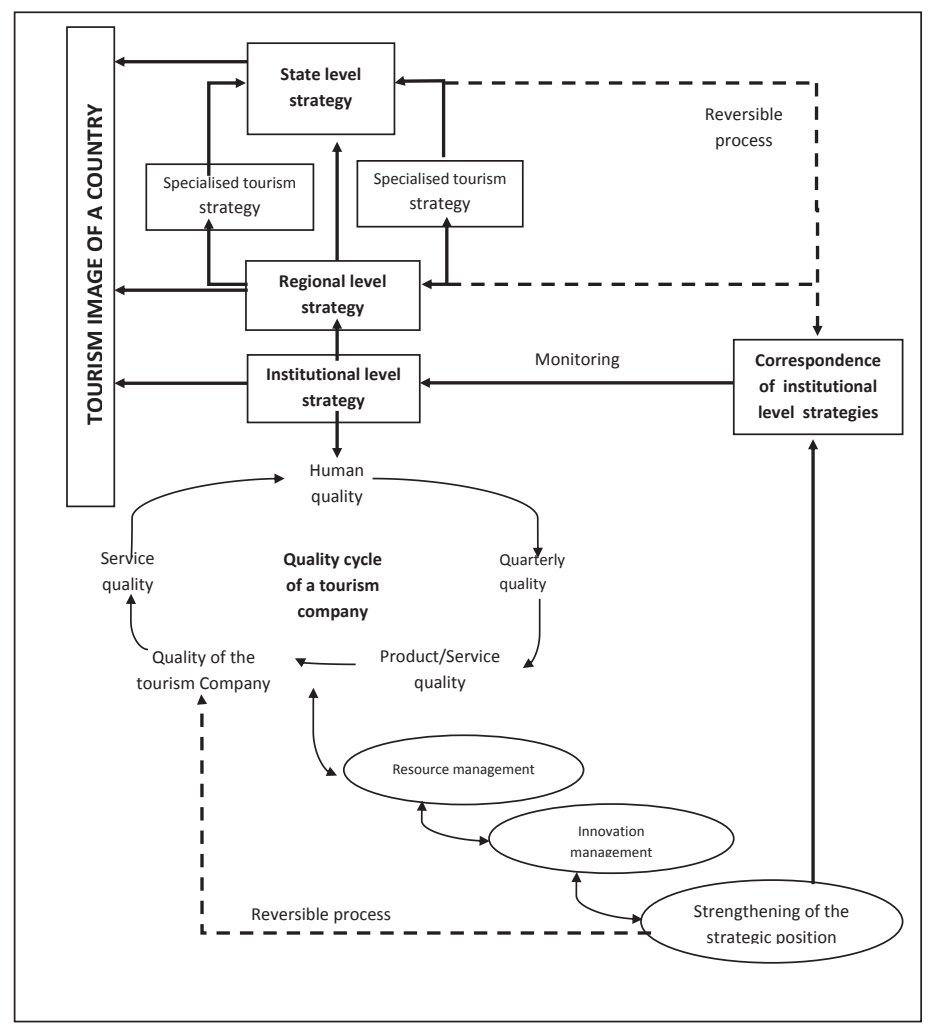


Figure 3. The proposed Lithuania's tourism strategy model [9, p. 85]Their proposed model, alongside characteristics of quality, also lists three characteristics of the competitiveness model cycle, seen also in Poon's model. They are resource management, innovation management, the strengthening of the strategic position. However, this model does not reveal the market-consumer relation. Fulfilling the needs of consumers is especially important in the business of cultural tourism. Users are less prone to emphasise the quality of services rather than, for example, local low-level and low importance sights included in the tour route. It is not uncommon that the objects included in the tour route do not meet the function of cultural tourism as an educational activity (sometimes even EU funds are used for their benefit, i.e., new recreational zones, longer walking paths). From this perspective, the marketing aspect is very important because of the better opportunities to meet the customers' needs by connecting cultural tourism with mote educational activities, e.g., history, cultural heritage, traditions, way of life, unique nature. To make strategic decisions in the area of cultural tourism, it is proposed to use a new model, grounded in the classical definition of strategic hierarchy and the specificities of cultural tourism as a business (Figure 4).

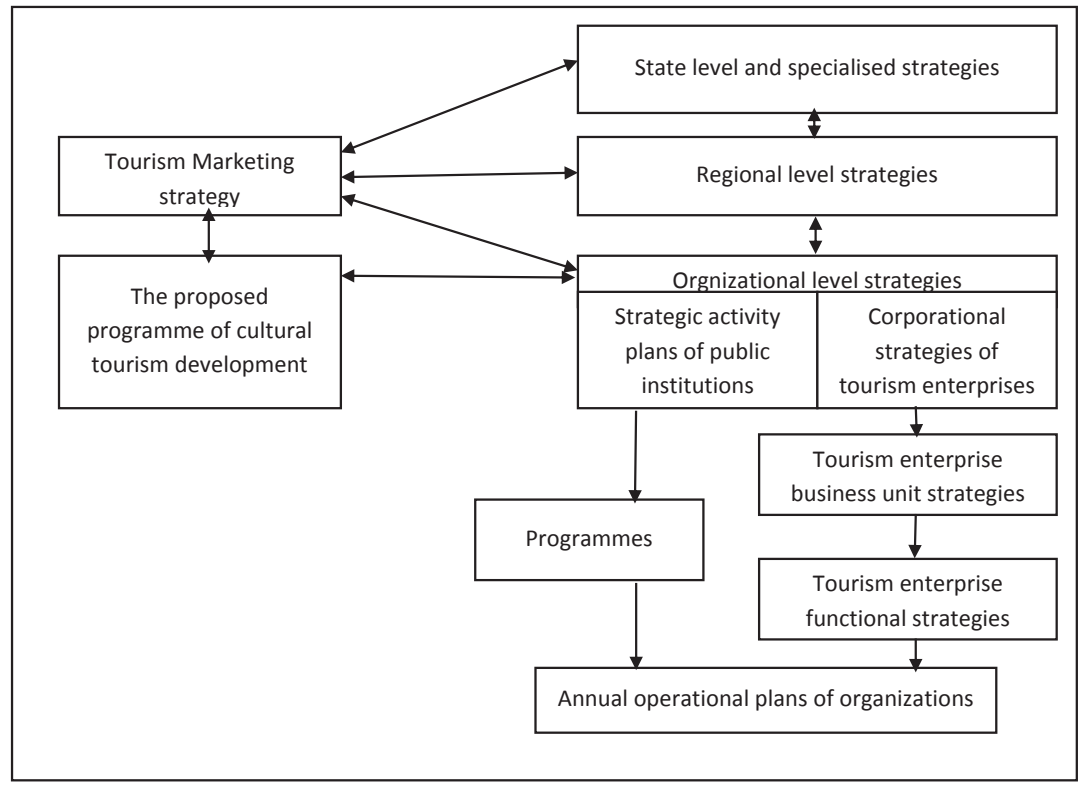

Figure 4. The proposed Lithuanian cultural tourism strategy development modelIn the proposed cultural tourism strategy development model, 4 levels of strategy creation can be seen: state, regional, institutional/organizational, business unit and functional level. Corporate and business unit strategies can coincide if the 
company specialises in one area, but if their activities are greatly diversified, each business unit can have separate strategies. The first of the functional strategies is the service provision strategy. Its aim is to create and materialize a coherent and competitive product in the market [10]. As a direct answer to the needs of consumers, the strategy of total quality can be chosen. Innovation strategy includes the creation of new services that meet the demand of the market and the management of innovation processes internally. The main objective of the finance management strategy is to develop such a structure of capital and its utilization which would help realize the other goals of the organization [7]. The finance management strategy should reflect the sources of finance and priorities, as well as attention to the short-term and longterm perspectives and the allocation of finances among different activities. The human resources strategy covers determining the criteria for selecting personnel, creating a long-term policy for salaries, developing the employee motivation and incentive system as well as their performance evaluation system and career planning. The marketing strategy is the business unit's efforts to present themselves better than their competitors, using its express advantage of being able to more successfully meet the demands of consumers in specific circumstances [10, p. 250]. The marketing strategy should determine markets, ways and measures of competition, provide the timeframe for implementing strategic actions.

Institutional level, general or corporate strategies in the area of cultural tourism can have many alternatives, growth strategies especially can be of many different varieties. Intense growth can be both as entering a market or maintaining it through more active marketing measures, expanding the market or improving tourism services. Growth can also be integrated, diversified or concentrated, various mergers between companies and common activities can be possible. If the demand for the services of cultural tourism would decrease, companies can choose stabilization, restructuration, activity reduction and turnaround strategy. Jucevičius opines that there is a need to distinguish two essential different types of turnaround strategies: strategic reorientation and operative reorientation [10].

These types of turnaround strategies respectively are also called entrepreneurial or effectiveness increasing turnarounds [23]. Operational reorientation is characterized by the fact that the general strategic orientation of the organization in its environment is not changed, but the priorities it functions on the operative level are changed. Strategic reorientation can be of two types: changing the accents of the strategy but staying in the same area of activity or when decisions on changing the activities are made [10, p. 311]. The provided model has no operational strategies because strategic objectives are rarely addressed at this level. Tourism companies usually have no strategies. The provided cultural tourism strategy development model should help the managers of cultural tourism companies to develop strategic thinking, which would express a reasoned perspective on what the consumer actually wants and how to meet their need using the subordination of the company's strategies. 


\section{Conclusions}

1. Different ministries are responsible for the protection of cultural heritage and managing cultural tourism in Lithuania and their activities are not integrated enough. To solve this problem, it is proposed to develop a cultural tourism development programme, which would be implemented through the strategic activity plans. Assignment holders themselves should decide on the ways to coordinate the programme.

2. The strategic purposefulness of the business of cultural tourism should be defined by four levels of strategy: integration, corporate, business unit and functional. The strategies of services/products, marketing, finance innovation and human resource development should be part of functional strategies.

3. The specificities of competitiveness of cultural tourism are characterized by competition in state, regional and institutional levels. Cultural tourism is closely related to the development of the state's and region's image, regions also compete amongst themselves for state grants, compete among themselves and separate companies providing tourism services. Marketing should be invariably developed in all of these levels.

4. Intense growth can be both as entering a market or maintaining it through more active marketing measures, expanding the market or improving tourism services. Growth can also be integrated, diversified or concentrated, various mergers between companies and common activities can be possible. If the demand for the services of cultural tourism decreases, companies can choose stabilization, restructuration, activity reduction and turnaround strategy. The main competition strategies in Lithuania remain low price, service differentiation and niche strategies.

\section{References}

1. Akma, J., and Sterry, P. Cultural Tourism in Africa: Strategies for the New Millennium. Proceedings of the ATLAS Africa International Conference, December, Mombasa, Kenya, 2000.

2. Bourgeois, L. J. Performance and Consensus. Strategic Management Journal. 1980, 1: 227-248.

3. Cabrini, L. Cultural Tourism: Opportunities and Challenges. Europen Forum of the World Heritage Cities. 2003.

4. Evans, N., et al. Strategic Management for Travel and Tourism. ASA: David Campbell and George Stonehouse, 2003.

5. Franko, L. G. Global Corporate Competition: Who's Winning, Who's Losing, and the R\&D Factor as One Reason Why. Strategic Management Journal. 1989, 10: 449-474.

6. Hall, M., and Zeppel, H. History, Architecture, Environment: Cultural Heritage and Tourism. Journal of Travel Research. 1990, 29(2): 54-55.

7. Harrison, J. S., and St.John, C. H. Strategic Management of Organizationsand Stakeholders: Theory and Cases. Minneapolis: West Publishing, 1994. 
8. Indriūnas, G. Kultūrinio turizmo plètra. [accessed on 2015-02-30]. <http://www.durys. org/konferencija/Gintautas\%20Indriunas.doc>.Janulienè, I., Žalienė, I., and Žalys, L. Peculiarities of Lithuania's Tourism Strategy Formulation. Organizacijų vadyba: sisteminiai tyrimai, 31. Kaunas: VDU, 2004.

9. Jucevičius, R. Strateginis organizacijų valdymas. Pasaulio lietuvių kultūros, mokslo ir švietimo centras, 1998.

10. Kahalas, H., and Suchon, K. Interview with Harold A. Poling, Chairman, CEO, Ford Motor Company. May, 1992.

11. Commission Communication. Europe, the World's No 1 Tourist Destination - A New Political Framework for Tourism in Europe. COM(2010) 352/final, 3 June 1990, Council Directive 90/314/EEC on Package Travel, Package Holidays and Package Tours.

12. Strategic Activity Plan (Code 14) of The Ministry of Culture of the Republic of Lithuania. [accessed on 2014-09-15]. <www.lrkm.lt/go.php/lit/Planai>.

13. Resolution of the Government of the Republic of Lithuania No. 194 "Regarding the Government's of the Republic of Lithuania's 6 June 2002 Resolution "Regarding the Confirmation of Change of the Strategic Planning Methodology"'. 2007 February 7, Vilnius. Valstybès žinios. 2003, Nr. 61-2804. Consolidated version from 2013-01-01.

14. National 2014-2020 Tourism Development Programme. [accessed on 2015-02-30]. $<$ http://www.min.litlex.lt/scripts/sarasas2.dll? Tekstas=1\&Id=177107\&Zd=PARTNERI $\mathrm{AI}>$.

15. Tourism Development Strategy up to 2015. [accessed on 2015-02-30]. <http:/www.lrti. 1t/veikla/turizmo_strat.doc $>$.

16. McKercher, B., and Cros Du, H. Cultural Tourism. The Partnership Between Tourism and Cultural Heritage Management. London: The Haworth Hospitality Press, 2002.

17. Poon, A. Tourism, Technology and Competitive Strategies. Wallingford: CABI, 1993.

18. Porter, M. E. Competitive Advantage: Creating and Sustaining Superior Performance. NY: FreePress, 1985.

19. Regional Development Plan Drafting Methodology. Approved with the 23 September 2011 Order No. IV-706 of the Minister of the Interior.

20. Regional 2011-2020 Culture Development Programme. [accessed on 2014-09-15]. $<$ https://www.alkas.lt/wp-content/uploads/2011/06/Regionu-programa1.pdf $>$.

21. Richards, G. The Social Context of Cultural Tourism. In: G. Richards (ed.). Cultural Tourism in Europe. Wallingford: CAB International, 1998.

22. Robbins, D. K., and Pearce II, J. A. Turnaround: Retrenchmentand Recovery. Strategic Management Journal. 1992, 13: 287-309.

23. Rugman, A. M., and Verbete, A. Corporate Strategies and Environmental Regulations: An Organizing Framework. Strategic Management Journal. 1998, 19: 363-375.

24. Silberberg, T. Cultural Tourism and Business Opportunities for Museums and Heritage Sites. Tourism Management. 1995, 16(2): 361-365.

25. Framework for Improving the Strategic Planning System of Municipalities Created by the Work Group under the 7 July 2011 Order No. 162 of the Prime Minister of the Republic of Lithuania.

26. Star, M. K. Global Competitiveness: Getting the U.S. Back to the Track. N.Y.: W.W. Norton, 1988.

27. Tighe, A. Research on Cultural Tourism in the United States. Travel and Tourism Research Association Proceedings, 1991, p. 387-391. 
28. Užpelkis, M. Darni plètra, kultūros paveldas ir turizmas. 2007 [accessed on 2015-0230]. <http://www.kultur.lt/dl.php?file=Paveldas+ir+darni+plètra.pdf $>$.

29. Žilinskas, J. V., Ligeikienè, R., Petravičienè, L. Turizmo strategijos formavimo modelis Lietuvoje. Ekonomika ir vadyba: aktualijos ir perspektyvos. 2007, 1(8): 305-311.

30. Žilinskas, J. V., Petravičienè, L. Turizmo verslas: plètros konceptualizacija ir tendencijos Lietuvoje. Ekonomika ir vadyba. 2007, 12.

\section{Malvina Arimavičiūtè}

\section{Kultūrinio turizmo strategijų vystymas Lietuvoje}

\section{Anotacija}

Straipsnyje nustatyta, kad kultūrinị turizmą Lietuvoje ženkliai veikia skirtingos žinybos, kurių veikla nėra pakankamai integruota. Išanalizuoti teoriniai modeliai strateginiams sprendimams priimti turizmo srityje bei strateginių sprendimų alternatyvų galimybès. Pateikta strateginių planų klasifikacija remiantis esama Lietuvos strateginio planavimo sistema ir atskirų žinybų veiklos integracija kultūrinio turizmo srityje. Siūlomas naujas modelis strateginiams sprendimams priimti kultūrinio turizmo srityje, remiantis klasikine strategiju hierarchijos samprata ir kultūrinio turizmo kaip verslo specifika.

Malvina Arimavičiūté - Mykolo Romerio universiteto Politikos ir vadybos fakulteto Vadybos instituto docentè, socialinių mokslų daktarè.

E. paštas arimaviciutė@gmail.com

Malvina Arimavičiūtè, Doctor of Social Sciences, Institute of Management, Faculty of Politics and Management, Mykolas Romeris Univeristy, Assoc. Prof.

E-mail: arimaviciutėgmail.com

Straipsnis įteiktas redakcijai $2015 \mathrm{~m}$. sausio mèn.; recenzuotas; parengtas spaudai $2015 \mathrm{~m}$. gegužès mèn. 